Atmos. Chem. Phys., 13, 6289-6304, 2013

www.atmos-chem-phys.net/13/6289/2013/

doi:10.5194/acp-13-6289-2013

(C) Author(s) 2013. CC Attribution 3.0 License.

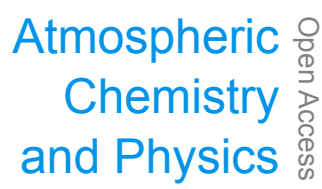

(c) (P)

\title{
Updated aerosol module and its application to simulate secondary organic aerosols during IMPACT campaign May 2008
}

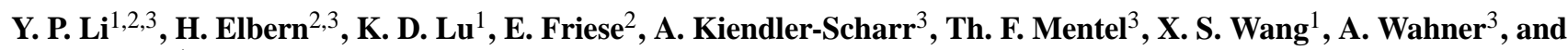 \\ Y. H. Zhang ${ }^{1}$ \\ ${ }^{1}$ State Key Joint Laboratory of Environmental Simulation and Pollution Control, College of Environmental Sciences and \\ Engineering, Peking University, Beijing, China \\ ${ }^{2}$ Rhenish Institute for Environmental Research at the University of Cologne, Cologne, Germany \\ ${ }^{3}$ Institut für Energie- und Klimaforschung Troposphäre (IEK-8), Forschungszentrum Jülich, Jülich, Germany
}

Correspondence to: Y. H. Zhang (yhzhang@pku.edu.cn)

Received: 20 February 2013 - Published in Atmos. Chem. Phys. Discuss.: 6 March 2013

Revised: 24 May 2013 - Accepted: 30 May 2013 - Published: 3 July 2013

\begin{abstract}
The formation of Secondary organic aerosol (SOA) was simulated with the Secondary ORGanic Aerosol Model (SORGAM) by a classical gas-particle partitioning concept, using the two-product model approach, which is widely used in chemical transport models. In this study, we extensively updated SORGAM including three major modifications: firstly, we derived temperature dependence functions of the SOA yields for aromatics and biogenic VOCs (volatile organic compounds), based on recent chamber studies within a sophisticated mathematic optimization framework; secondly, we implemented the SOA formation pathways from photo oxidation ( $\mathrm{OH}$ initiated) of isoprene; thirdly, we implemented the SOA formation channel from $\mathrm{NO}_{3}$-initiated oxidation of reactive biogenic hydrocarbons (isoprene and monoterpenes). The temperature dependence functions of the SOA yields were validated against available chamber experiments, and the updated SORGAM with temperature dependence functions was evaluated with the chamber data. Good performance was found with the normalized mean error of less than $30 \%$. Moreover, the whole updated SORGAM module was validated against ambient SOA observations represented by the summed oxygenated organic aerosol (OOA) concentrations abstracted from aerosol mass spectrometer (AMS) measurements at a rural site near Rotterdam, the Netherlands, performed during the IMPACT campaign in May 2008. In this case, we embedded both the original and the updated SORGAM module into the EURopean Air pollution and Dispersion-Inverse Model (EURAD-IM), which showed general good agreements with the observed meteo-
\end{abstract}

rological parameters and several secondary products such as $\mathrm{O}_{3}$, sulfate and nitrate. With the updated SORGAM module, the EURAD-IM model also captured the observed SOA concentrations reasonably well especially those during nighttime. In contrast, the EURAD-IM model before update underestimated the observations by a factor of up to 5. The large improvements of the modeled SOA concentrations by updated SORGAM were attributed to the mentioned three modifications. Embedding the temperature dependence functions of the SOA yields, including the new pathways from isoprene photo oxidations, and switching on the SOA formation from $\mathrm{NO}_{3}$ initiated biogenic VOC oxidations, contributed to this enhancement by 10, 22 and $47 \%$, respectively. However, the EURAD-IM model with updated SORGAM still clearly underestimated the afternoon SOA observations up to a factor of two.

\section{Introduction}

At local or regional scales, fine particle pollution is one of the central concerns of air pollution control due to its negative health impacts, degradation of visibility, and potential role as surface for heterogeneous reactions. According to the available ambient measurements performed at urban, urban downwind area and rural locations, organic aerosol comprises a major fraction of submicron particulates (Zhang et al., 2007); of which, secondary organic aerosol (SOA) is a significant portion (Hallquist et al., 2009; Heald et al., 2005). However,

Published by Copernicus Publications on behalf of the European Geosciences Union. 
it is still a challenging work to simulate SOA using chemical transport models, as both the diagnosis and prediction of the fine particle pollution from local to global scales are still uncertain, yet form a basis for projecting climate change and regional air pollution control.

Several chemical transport models (CTM), such as GEOSCHEM, Community Multiscale Air Quality (CMAQ), and PM Comprehensive Air Quality Model (PMCAMx) (Fu et al., 2008; Carlton et al., 2010; Lane et al., 2008), were employed to simulate SOA formation. However, there was large uncertainty of current models to predict SOA in the atmosphere due to the large varieties of SOA precursors and processes involved in formation of SOA (Hallquist et al., 2009). A new study even indicated that the equilibrium partitioning method used in traditional models might be questionable at real atmospheric conditions (Perraud et al., 2012). Widely used frameworks to simulate SOA formation processes include e.g., the two-product model approach (Odum et al., 1996), methods based on volatility basis set (VBS, Donahue et al., 2006) such as the 2D-VBS (Jimenez et al., 2009) and statistical oxidation model (SOM, Cappa et al., 2013). Additionally in recent studies, other new frameworks such as the condensed aromatic kinetics (Kamens et al., 2011; Zhou et al., 2011) and the functional group oxidation model (Zhang et al., 2012) were developed as well.

The EURopean Air pollution and Dispersion-Inverse Model (EURAD-IM, Elbern et al., 2007) is an Eulerian model running from local to continental scale. EURAD-IM is primarily used for chemical weather forecast and advanced data assimilation studies over Europe. Previous studies on a high ozone episode (Monteiro et al., 2012) and a dust storm (Chervenkov and Jakobs, 2011) indicated good performances of EURAD-IM. Colette et al. (2011) compared six CTMs including BOLCHEM, CHIMERE, EMEP, EURAD, OSLOCTM2 and MOZART used for simulations of the European air quality. It was found that EURAD-IM was best in simulating $\mathrm{NO}_{2}$ and $\mathrm{PM}_{10}$ among all six CTMs. The SOA module in EURAD, namely, Secondary ORGanic Aerosol Model (SORGAM, Schell et al., 2001), is based on the twoproduct approach, but the performance of the SOA simulations by EURAD-IM is rarely evaluated against European ambient measurements.

Fundamental knowledge of SOA formation was largely developed in the last two decades. New precursors or new pathways of the oxidation of known precursors were recognized and sequentially implemented into the model. The photo oxidation products of monoterpenes and aromatics were firstly considered and determined to contribute to the aerosol budget due to their relative large carbon skeleton (Kavouras et al., 1998; Odum et al., 1997). In contrast, isoprene, the most prominent ambient volatile organic component (VOC; Kesselmeier and Staudt, 1999; Guenther et al., 1996, 2006) was initially not considered to be a possible SOA precursor, as it is a small molecule (Pandis et al., 1991). However, interesting indications that isoprene could be an important SOA precursor started to appear when Claeys et al. (2004) detected two polyols containing the isoprene skeleton in ambient aerosol samples. Furthermore, followed by the parameterization given by Kroll et al. (2006), a global model study estimated that including the isoprene generated SOA formation increased the simulated aerosol burden by a factor of two (Henze and Seinfeld, 2006). In a recent kinetic study, Paulot et al. (2009) proposed that isoprene derived epoxides and the subsequent formation of polymers on aerosols could be one important physical mechanism for isoprene SOA formation. Moreover, recent studies also highlighted the importance of reactive nitrogen compounds in global SOA formation. For example, $\mathrm{NO}_{3}$ radical initiated oxidation of VOCs was found to be very important for SOA formation during nighttime conditions (Fry et al., 2009, 2011; Rollins et al., 2009; Pye et al., 2010).

In addition to the chemistry, ambient conditions such as temperature and humidity can also strongly influence the SOA production rates as observed in a series of chamber experiments. Temperature was reported as an important factor (Chung and Seinfeld, 2002), influencing the SOA yield from a given gas phase precursor-oxidant combination. The influence of temperature is manifold as it can affect the gasphase oxidation mechanism, thus shifting the product distribution, as well as the partitioning of vapors between the gas phase and the particulate phase. Photo-oxidation experiments in a temperature-controlled chamber showed that, for three aromatic hydrocarbons (toluene, $m$-xylene and 1,2,4trimethylbenzene), $\alpha$-pinene and $n$-undecane (Takekawa et al., 2003), the SOA yield at $283 \mathrm{~K}$ was approximately twice as much than at $303 \mathrm{~K}$. On the other hand, at very low temperature (between $243 \mathrm{~K}$ and $273 \mathrm{~K}$ ), positive temperature dependence was observed and ascribed to changes in chemical kinetics (Jonsson et al., 2008). For SOA formed from $m$-xylene, a transition point near $290-292 \mathrm{~K}$ was observed for SOA density, volatility, hygroscopicity and elemental composition, when the experimental temperatures were increased. This indicated that simply employing the enthalpy of vaporization was not sufficient in predicting temperature dependent SOA formation (Qi et al., 2010). In addition, the influence of humidity on SOA formation was shown in former works (Seinfeld et al., 2001; Seinfeld and Pankow, 2003). More SOA mass was produced from the same amount of $\alpha$-pinene under humid than under dry conditions, with the total yield increasing about four times at both high and low temperatures (Tillmann et al., 2010). Here reaction channels involving water led to the formation of products with lower vapor pressures.

To transfer the chamber studies into model frameworks, parameterizations of SOA formation are needed. Chamber experiments on the effect of temperature on the SOA formation from ozonolysis of $\alpha$-pinene and limonene were reported by Saathoff et al. (2009). They used the COSIMA-SOA model (Naumann et al., 2003) to reproduce the observed SOA mass, number and size distributions by parameterizing 
the temperature dependence of mass stoichiometric and partitioning coefficients. Stanier et al. (2008) used experimental smog chamber data of $\alpha$-pinene ozonolysis to parameterize the aerosol mass fractions. Based on the theory of absorptive partitioning and the method of the VBS, a nonlinear least squares fitting tool was employed to calculate the mass stoichiometric coefficient and the enthalpy of vaporization. However, the parameterizations in recent works (e.g., Saathoff et al., 2009) were usually derived from one group of experiments, which might not be representative. In some cases (Stanier et al., 2008) temperature sensitivity was considered based on multi-researches, but without providing an explicit function to describe the relations among the researches. In most chemical transport models (e.g., Henze and Seinfeld, 2006; Carlton et al., 2010), mass stoichiometric and partitioning coefficients are set to constant values at a reference temperature $(298 \mathrm{~K})$, and the enthalpy of vaporization is applied to calculate values at other temperatures. However, in many cases the enthalpy of vaporization is not known well, which might result in large uncertainties.

In the present work, we updated the aerosol module SORGAM with temperature dependent parameterizations of SOA formation considering published chamber experiments of relevance (indicated by the suffix T), we included the SOA formation pathways from isoprene oxidation (indicated by I), and the degradation products initiated by $\mathrm{NO}_{3}$ oxidation were also considered (N). The stepwise updated SORGAMTIN module was first validated in a box model framework with chamber experiments and then tested in the EURADIM platform in a case study. Model and measurement comparison of the SOA concentrations at a rural location near Rotterdam (the Netherlands) further proved the success of these updates under real European atmospheric conditions.

\section{Methodology}

\subsection{Current aerosol module in EURAD-IM}

Within EURAD-IM, the aerosol dynamics such as nucleation, condensation, coagulation, diffusion, sedimentation, aerosol-cloud interaction, etc. are simulated by the Modal Aerosol Dynamics Model for Europe (MADE) (Ackermann et al., 1998). However, the initial MADE aerosol chemistry module only treated inorganic ions and water. To consider the formation of secondary organic aerosols, SORGAM was developed and implemented into MADE (Schell et al., 2001). In SORGAM, both anthropogenic and biogenic hydrocarbons are first oxidized by oxidants like $\mathrm{OH}, \mathrm{NO}_{3}$ and $\mathrm{O}_{3}$. The mass transfer from gas to particle phase is then driven by the gas/particle partitioning of the low volatility oxidation products formed in gas phase. According to the available chamber experimental results, the fractional aerosol coefficient is used for the oxidations of alkanes and anthropogenic terminal and internal alkenes, while the two-product model is applied for other reactive organic gases including aromatics and terpenes.

For the two-product model approach (Odum et al., 1996) used in SORGAM, the produced SOA from oxidation of certain hydrocarbon precursor is expressed by

$Y=\frac{M_{0} \alpha_{1} K_{1}}{1+K_{1} M_{0}}+\frac{M_{0} \alpha_{2} K_{2}}{1+K_{2} M_{0}}$,

where $Y$ is the mass fractional yield of SOA, $M_{0}$ is the total aerosol organic mass concentration, $\alpha_{i}$ is the mass stoichiometric coefficient, and $K_{i}$ is a partitioning coefficient. The subscripts 1 and 2 in Eq. (1) denote the two categories of oxidation products, normally one is assumed to be semivolatile and the other is attributed to low-volatile condensable vapors. In the original SORGAM, the mass stoichiometric coefficients $\alpha_{i}$ are set to be constants, and the influence of temperature is solely introduced through partitioning coefficients $K_{i}$ whose temperature dependence is expressed using the Clausius-Clapeyron equation (Pankow, 1987).

In this work, we updated the SORGAM model to SORGAM-TIN in the following five aspects (for a schematic view see Fig. 1): (1) enthalpies of vaporization were updated according to a recent study (Saathoff et al., 2009); (2) the influence of aerosol water content on the SOA yield was considered by a simplified RH (relative humidity) dependence correction; (3) unified temperature dependent functions of mass stoichiometric coefficients and partitioning coefficients for the two-product approach were derived according to available chamber experiments; (4) the SOA produced from isoprene oxidation products was considered; and (5) the SOA produced from the degradation products of biogenic VOCs by $\mathrm{NO}_{3}$ was considered as well.

\subsection{Update of enthalpies of vaporization}

The SOA two-product species in MADE/SORGAM and their molecular weights and enthalpies of vaporization were listed in Table 1 . The enthalpies of vaporization of every product from all precursors were the same in the original SORGAM (Schell et al., 2001) with the following exceptions: the enthalpies of vaporization of the products of $\alpha$-pinene and limonene were updated according to Saathoff et al. (2009); molecular weights and enthalpies of vaporization of the products of isoprene were taken from Carlton et al. (2010) and Kleindienst et al. (2009).

\subsection{Humidity correction}

For the parameterization of SOA formation, the effect of humidity was considered in this study. According to Prisle et al. (2010), the activity suppression in the Raoult's law region is a linear function of $\mathrm{RH}$ for any organic compound $i$ :

$\tau_{i}(\mathrm{RH})=1-\varsigma_{i} \cdot \mathrm{RH}$, 
Table 1. SOA two-product species in SORGAM module.

\begin{tabular}{lllll}
\hline RACM Precursor Classes & Oxidants & SOA Model Classes & MW $\left(\mathrm{g} \mathrm{mol}^{-1}\right)$ & $\Delta H_{\text {vap }}\left(\mathrm{kJ} \mathrm{mol}^{-1}\right)$ \\
\hline TOL, XYL, CSL & $\mathrm{OH} / \mathrm{NO}_{3}$ & ARO1 & 150 & 156 \\
& & ARO2 & 150 & 156 \\
\hline $\mathrm{HC}$ & $\mathrm{OH}$ & ALK1 & 140 & 156 \\
\hline OLT, OLI & $\mathrm{O}_{3} / \mathrm{OH} / \mathrm{NO}_{3}$ & OLE1 & 140 & 156 \\
\hline API & $\mathrm{O}_{3} / \mathrm{OH} / \mathbf{N O}_{3}$ & API1 & 184 & $\mathbf{2 4}^{\mathrm{a}}$ \\
& & API2 & 184 & $\mathbf{5 9}^{\mathrm{a}}$ \\
\hline LIM & $\mathrm{O}_{3} / \mathrm{OH} / \mathbf{N O}_{3}$ & LIM1 & 200 & $\mathbf{2 5}^{\mathrm{a}}$ \\
& & LIM2 & 200 & $\mathbf{5 5}^{\mathrm{a}}$ \\
\hline ISO & $\mathbf{O}_{3} / \mathbf{O H} / \mathbf{N O}_{3}$ & ISO1 & $96^{\mathrm{b}}$ & $\mathbf{3 9}^{\mathrm{c}}$ \\
& & ISO2 & $\mathbf{9 6}^{\mathbf{b}}$ & $\mathbf{3 9}^{\mathrm{c}}$ \\
\hline
\end{tabular}

${ }^{a}$ Saathoff et al. (2009)

b Carlton et al. (2010)

c Kleindienst et al. (2009)

Bold type: updates of original SORGAM

(TOL: toluene and less reactive aromatics; XYL: xylene and more reactive aromatics; CSL: cresol and other hydroxyl substituted aromatics; HC: alkanes; OLT: terminal alkenes; OLI: internal alkenes; API: $\alpha$-pinene and other cyclic terpenes with one double bond; LIM: limonene and other cyclic diene-terpenes; ISO: isoprene.)

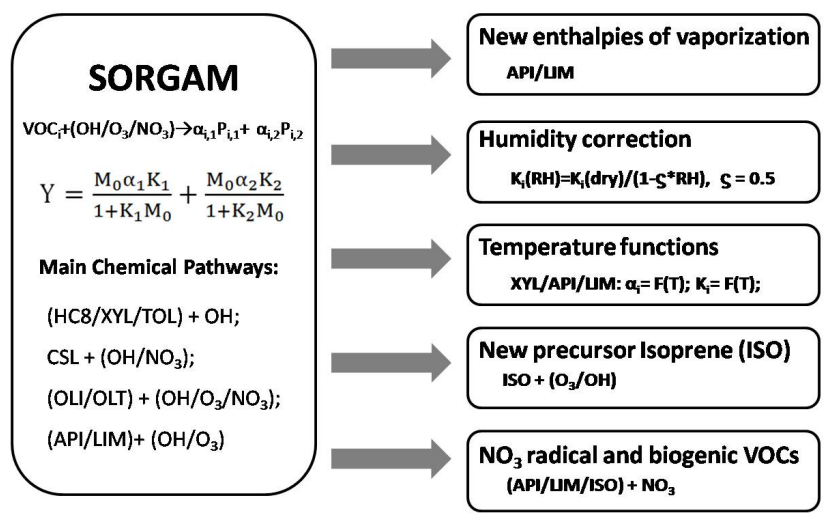

Fig. 1. A schematic view of the updates we applied to the original SORGAM module.

$\mathrm{C}_{i}^{*}(\mathrm{RH})=\tau_{i} \mathrm{C}_{i}^{*}(\mathrm{dry}$,

where $\tau_{i}, \varsigma_{i}, C_{i}^{*}$ and RH denote organic activity coefficient, hydrophilicity coefficient, saturation mass concentration and relative humidity, respectively. Based on $\alpha$-pinene ozonolysis, Prisle et al. (2010) estimated the range of $\zeta$ varying from 0.33 to 0.67 , and within the error limits nearly all the results could be represented by $\varsigma=0.5$. Therefore in this study, $\varsigma$ was set to 0.5 for all organic compounds included in SORGAM-TIN. Since $C_{i}^{*}$ is the reciprocal of the partitioning coefficient $K_{i}, K_{i}(\mathrm{RH})$ can be expressed as $K_{i}($ dry $) /$ $(1-\varsigma \cdot \mathrm{RH})$. Equation (1) can thus be rearranged to

$Y=\frac{M_{0} \alpha_{1} K_{1} /(1-\varsigma \cdot \mathrm{RH})}{1+K_{1} M_{0} /(1-\varsigma \cdot \mathrm{RH})}+\frac{M_{0} \alpha_{2} K_{2} /(1-\varsigma \cdot \mathrm{RH})}{1+K_{2} M_{0} /(1-\varsigma \cdot \mathrm{RH})}$.

\subsection{Temperature dependent functions of mass stoichio- metric coefficients and partitioning coefficients}

It was found that the original parameterization of $\alpha_{i}$ and $K_{i}$ in SORGAM could not describe the available recent chamber experimental results appropriately. With newly available laboratory data collected and reviewed, we deduced new parameterizations of $\alpha_{i}$ and $K_{i}$ with sophisticated non-linear optimization software packages such as Lsqnonlin, Eureqa (Schmidt and Lipson, 2009) and N12sol (Dennis et al., 1981). The above humidity correction was included in this parameterization as well. Taking $\alpha$-pinene as an example, at $T=$ $293 \mathrm{~K}$ and $M_{0}=5 \mu \mathrm{g} \mathrm{m}^{-3}$, the yield of SOA increased $2.5 \%$ at $\mathrm{RH}=50 \%$, as calculated by Eq. (4). In Fig. 2, the methodological framework of the parameterization was depicted, which included three major steps.

Firstly, the selected chamber experimental data were grouped into different temperature bins to deduce the relation between parameters and the temperature in each bin. According to Eq. (1), experimentally determined $Y$ and $M_{0}$ are used as input data while the other four parameters $\left(\alpha_{1}, K_{1}, \alpha_{2}, K_{2}\right)$ were deduced in each temperature bin with Lsqnonlin (an optimization tool in Matlab to solve non-linear least squares problems). The results of this step can be summarized as $Y_{T_{i}}=F\left(M_{0}, \alpha_{1}\left(T_{i}\right), \alpha_{2}\left(T_{i}\right), K_{1}\left(T_{i}\right), K_{2}\left(T_{i}\right)\right)$.

In the second step, we further established the relationship between temperature and the four parameters. With Eureqa, a software tool for detecting equations and hidden mathematical relationships in data (Schmidt and Lipson, 2009), we derived intermediate functions relating the stoichiometric coefficients $\alpha_{i}$ or partitioning coefficients $K_{i}$ with temperature:

$\alpha_{1}=F_{1}(T) ; \alpha_{2}=F_{2}(T) ; K_{1}=F_{3}(T) ; K_{2}=F_{4}(T)$. 


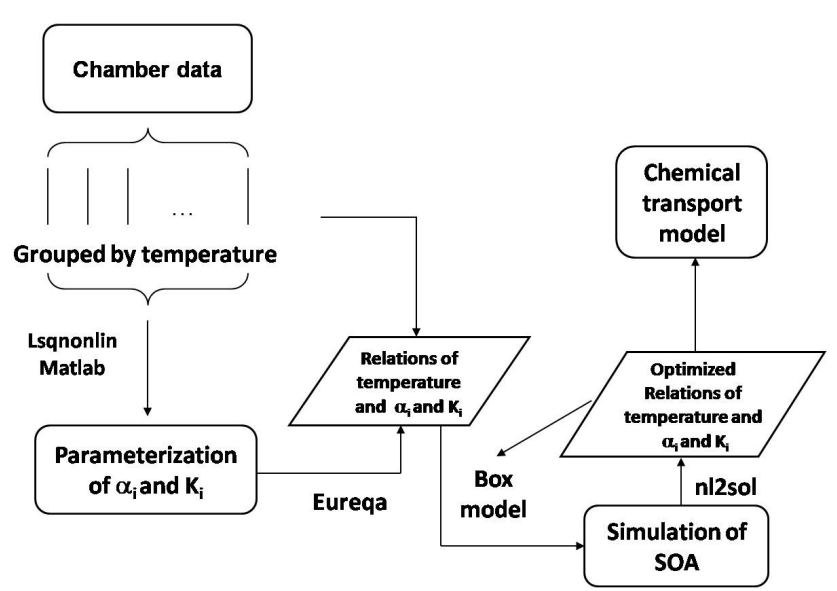

Fig. 2. Technical frame of parameterization of mass stoichiometric coefficients and partitioning coefficients. First step: grouping experimental data, second step: fitting parameters in each group, third step: deriving temperature dependent functions, last step: optimizing parameter functions.

The functions $F_{i}$ derived in the second step were tested in a box model framework. However, the model-measurement inter-comparison results were not as satisfying as expected (see Sect. 3.2), due to the different algorithm utilized in Eureqa and SORGAM. Therefore, in a third step, the localized parameterization of the functions $F_{i}$ for SORGAM has to be further deduced. This kind of optimization was achieved with the N12sol model, which is an adaptive nonlinear least-squares algorithm. Herein, the residual vector, i.e., the differences of simulated and observed values, is a continuously differentiable function $R(x)=\left(R_{1}(x), \ldots, R_{n}(x)\right)^{T}$ of $p$ parameters $x=\left(x_{1}, \ldots, x_{p}\right)^{T}$. Vector $\boldsymbol{x}$ was introduced in the temperature functions like $F_{i}(T, x)$, and the initial value of $\boldsymbol{x}$ was set as 1.0. Nl2sol attempts to find a parameter vector $x^{*}$ that minimizes the sum of squares function $F(x)=\sum R_{i}(x)^{2}$ (Dennis et al., 1981). In this way, the final functions $F_{i}\left(T, x^{*}\right)$ with best compatibility for SORGAM were obtained.

Due to the limited amount of chamber experiments for toluene, the temperature dependence functions for the parameterizations of toluene were extrapolated from those of $m$-xylene. In a study by Takekawa et al. (2003) both toluene and $m$-xylene were investigated under similar experimental conditions. We subdivided these experiments into two temperature groups, namely, $283 \mathrm{~K}$ and $303 \mathrm{~K}$. By assuming that the oxidation products of $m$-xylene and toluene had the same partitioning coefficient $K_{i}$, we thus derived the mass stoichiometric coefficient of toluene: $\alpha_{\text {toluene }}=x \cdot \alpha_{\mathrm{m}-\mathrm{xylene}}$, $x>1$ (Vivanco et al., 2011). We then solved $x$ by Eq. (1) for both temperature groups according to available chamber experiments (Takekawa et al., 2003). Linear interpolation between the two temperatures was performed to get the function for factor $x$ :
$x=(T-283) \cdot 0.12+1.2$.

\subsection{Mechanistic updates}

In the original SORGAM, SOA produced from isoprene was not considered. In contrast, as outlined in recent laboratory and field studies (e.g., Claeys et al., 2004; Kroll et al., 2006; Henze and Seinfeld, 2006; Paulot et al., 2009), isoprene could be a more important precursor of SOA than previously thought. Nevertheless, the laboratory results about the SOA yield from isoprene were still limited (Chhabra et al., 2010; Dommen et al., 2006; Kroll et al., 2006), so there are not enough data available to derive temperature dependent functions of $\alpha$ and $K$. Instead, a constant $\alpha$ valid at $295 \mathrm{~K}$ determined by the $\mathrm{OH}$ oxidation of isoprene was adapted according to Henze and Seinfeld (2006).

$\mathrm{ISO}+\mathrm{OH} \rightarrow 0.0288 \cdot \mathrm{ISO} 1+0.232 \cdot \mathrm{ISO} 2$

The set of parameters shown in Eq. (6) is widely used in CTMs, including GEOS-Chem and CMAQ (Henze and Seinfeld, 2006; Carlton et al., 2010). In addition, the reaction of isoprene and ozone was not included, since this reaction channel does not produce SOA (Pye et al., 2010).

In the original SORGAM, the SOA yields from reactions of $\mathrm{NO}_{3}$ with terpenes are assumed to be zero according to Griffin et al. (1999) and the reaction of $\mathrm{NO}_{3}$ with isoprene is not considered. In this study, oxidation of $\alpha$-pinene, limonene and isoprene by $\mathrm{NO}_{3}$ radical was taken into account according, to the current state of knowledge (Pye et al., 2010). The partitioning coefficients $K_{i}$ for $\alpha$-pinene and limonene were calculated with the temperature functions in Table 3. The mass stoichiometric coefficients $\alpha_{i}$ for the reaction of isoprene with $\mathrm{NO}_{3}$ were set to the largest value experimentally determined by $\mathrm{Ng}$ et al. (2008):

$\mathrm{ISO}+\mathrm{NO}_{3} \rightarrow 0.217 \cdot \mathrm{ISO} 1+0.217 \cdot \mathrm{ISO} 2$.

The mass stoichiometric coefficients $\alpha_{i}$ for $\alpha$-pinene and limonene were referred to the $\mathrm{NO}_{3}$ experiments as shown by Table 4 of Griffin et al. (1999). In those experiments, an extremely high aerosol yield $(\alpha=1)$ was determined for the $\mathrm{NO}_{3}$ oxidation of bicyclic terpenes. To be compatible with the two-product model applied in SORGAM, it was assumed there were two products with the same stoichiometric coefficients of 0.5 :

$\mathrm{API}+\mathrm{NO}_{3} \rightarrow 0.5 \cdot \mathrm{API} 1+0.5 \cdot \mathrm{API} 2$,

$\mathrm{LIM}+\mathrm{NO}_{3} \rightarrow 0.5 \cdot \mathrm{LIM} 1+0.5 \cdot \mathrm{LIM} 2$.

The mechanistic update of the SORGAM module with respect to the $\mathrm{NO}_{3}$ oxidation in this study is in line with the current development of GEOS-Chem (Pye et al., 2010; Yu, 2011) and CMAQ (Carlton et al., 2010). 

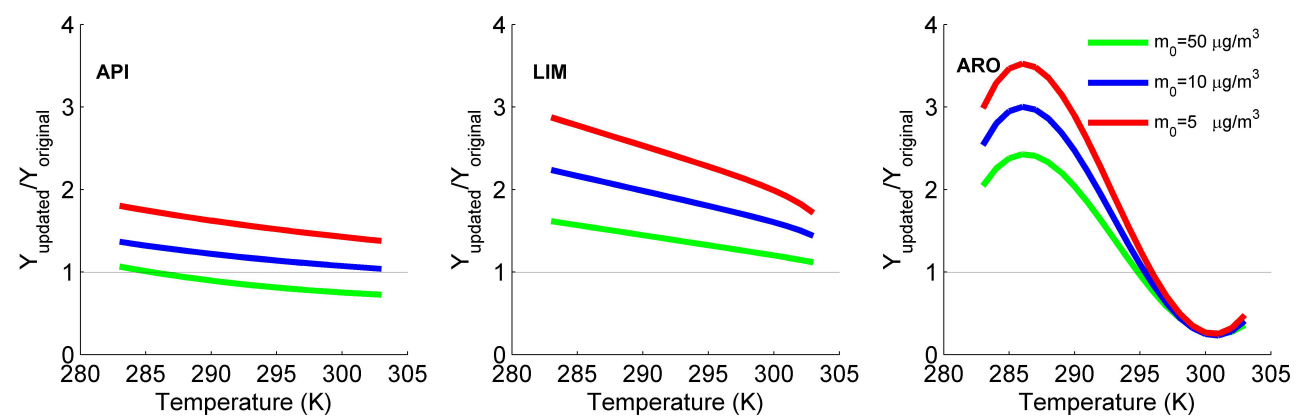

Fig. 3. Temperature dependence of the ratio between the updated SOA yields ( $Y_{\text {updated }}$ ) calculated with temperature parameterized $\alpha$ and $K$ and the original SOA yields ( $Y_{\text {original }}$ ) used in SORGAM for mechanistic categories API, LIM and ARO for 3 different mass concentrations.

\section{Results and discussions}

\subsection{Unified temperature parameterized functions - $\alpha(T)$ and $K(T)$}

According to recent chamber studies, the SOA yields were found to vary significantly for different parent hydrocarbons and experiment conditions such as temperature. Since data are relatively abundant to characterize the temperature dependence for $\alpha$-pinene, limonene and $m$-xylene, chamber studies with similar experimental conditions were used to derive unified temperature parameterized functions for $\alpha$ and $K$. In this study, we grouped the available ozonolysis experiments for $\alpha$-pinene and limonene, and photo-oxidation $(\mathrm{OH}$ initiated) experiments for $m$-xylene (Chen and Hopke, 2010; Cocker et al., 2001a, b; Griffin et al., 1999; Hoffmann et al., 1997; Kamens et al., 1999; Odum et al., 1996; Offenberg et al., 2007; Pathak et al., 2007a, b; Presto et al., 2005; Presto and Donahue, 2006; Saathoff et al., 2009; Sarwar et al., 2007; Takekawa et al., 2003; Warren et al., 2009; Yu et al., 1999) as described in Table 2. Due to the fact that records of $\alpha$ pinene chamber data were more abundant than others, we were able to define 14 temperature bins ranging from 243 to $320 \mathrm{~K}$. Limonene data, available in the temperature range of 253 to $313 \mathrm{~K}$, was divided into 6 bins. Only 4 bins were used for $m$-xylene, since the temperature range of experimental data was quite limited ( 283 to $303 \mathrm{~K}$ ).

Following the methodology described in Sect. 2.4, we derived unified temperature dependent functions for the mass stoichiometric coefficient $\alpha(T)$ and for the gas-particle partitioning coefficient $K(T)$ for $\alpha$-pinene, limonene and $m$ xylene, as shown in Table 3. We limited the form of the functions as the fundamental arithmetic in Eureqa to make them more tractable. On the other hand, the accuracy was considered as well. If a linear function could not reflect the relation between temperature and a parameter, the order of the function was increased, but not higher than 3. In SORGAMTIN, the derived $\alpha(T)$ and $K(T)$ are extended to all oxidation pathways of $\alpha$-pinene, limonene and $m$-xylene assuming that similar oxidation products are produced from $\mathrm{OH}, \mathrm{NO}_{3}$ and $\mathrm{O}_{3}$. According to the main reaction pathway of each precursor, the uncertainty of the extrapolation was estimated no more than $24 \%$.

To evaluate the effect of the newly derived $\alpha(T)$ and $K(T)$, the temperature dependence of the ratio of the updated SOA yield against the original yield $\left(Y_{\text {updated }} / Y_{\text {original }}\right)$ for $\alpha$-pinene, limonene and $m$-xylene are further analyzed and displayed in Fig. 3. Limited by the available experimental data, the derived $\alpha(T)$ and $K(T)$ is only suitable from $283 \mathrm{~K}$ to $304 \mathrm{~K}$. In case the temperature exceeds the scales, the $\alpha(T)$ and $K(T)$ will be set as $\alpha(283), K(283)$ and $\alpha(304)$, $K(304)$ respectively. In Fig. 3, the yields are calculated based on Eq. (1), and three $M_{0}$ values $\left(5,10,50 \mu \mathrm{g} \mathrm{m}^{-3}\right)$ are selected for different cases. For $\alpha$-pinene, updated SOA yields are higher at low $M_{0}$ concentration $\left(Y_{\text {updated }} / Y_{\text {original }}\right.$ up to 1.80 and 1.37 with $M_{0}=5$ and $10 \mu \mathrm{g} \mathrm{m}^{-3}$ at lower temperature, respectively). However, when $M_{0}$ is high, the updated yields are lower at higher temperatures ( $>286 \mathrm{~K})$. For limonene, systematic higher SOA yields are shown in the updated model, with the ratio of $Y_{\text {updated }} / Y_{\text {original }}$ up to 2.87, 2.24 and 1.62 at lower temperature, based on different $M_{0}$ load, respectively. For $m$-xylene, the updated SOA yields are higher $\left(Y_{\text {updated }} / Y_{\text {original }}\right.$ up to $2.43,3.00$ and 3.52 at different $\left.M_{0}\right)$ at lower temperatures $(<295 \mathrm{~K})$ while lower ( $Y_{\text {updated }} / Y_{\text {original }}$ down to about 0.24$)$ at higher temperatures (> $295 \mathrm{~K})$.

\subsection{Performance of the derived $\alpha(T)$ and $K(T)$ in chamber experiments}

In chamber experiments for $\alpha$-pinene, the oxidant was ozone, and the concentrations of $\alpha$-pinene ranged from 45 to 692 $\mu \mathrm{g} \mathrm{m}^{-3}$ (average: $229 \mu \mathrm{g} \mathrm{m}^{-3}$ ). In about half of the experiments, seed aerosol was used (as $\left(\mathrm{NH}_{4}\right)_{2} \mathrm{SO}_{4}$ or $\mathrm{NH}_{4} \mathrm{HSO}_{4}$ ). The largest relative humidity in the experiments was $73 \%$, but in most experiments, the RH was lower than $50 \%$, and in more than half of the experiments, the RH was very low $(<10 \%)$. For limonene, the main oxidant was ozone as well, and the concentrations of limonene ranged from 18 to $203 \mu \mathrm{g} \mathrm{m}^{-3}$ (average: $112 \mu \mathrm{g} \mathrm{m}^{-3}$ ). There were no seed 
Table 2. Temperature grouping of the ozonolysis experiments of $\alpha$-pinene and limonene, and photo-oxidation (OH initiated) experiments of $m$-xylene for deriving unified temperature parameterized functions for $\alpha$ and $K$.

\begin{tabular}{llllll|lll|l|lll}
\hline \multicolumn{4}{c}{$\alpha$-pinene } & \multicolumn{3}{c|}{ Limonene } & \multicolumn{3}{c}{$m$-xylene } \\
\hline No. & $T$ & Data points & No. & $T$ & Data points & No. & $T$ & Data points & No. & $T$ & Data points \\
\hline 1 & 243 & 3 & 8 & 295 & 19 & 1 & 253 & 2 & 1 & 283 & 3 \\
2 & 252 & 2 & 9 & 300 & 11 & 2 & 273 & 1 & 2 & 293 & 22 \\
3 & 273 & 4 & 10 & 301 & 12 & 3 & 293 & 3 & 3 & 298 & 10 \\
4 & 278 & 7 & 11 & 302 & 23 & 4 & 296 & 9 & 4 & 303 & 3 \\
5 & 284 & 2 & 12 & 303 & 16 & 5 & 303 & 1 & & & \\
6 & 288 & 11 & 13 & 313 & 22 & 6 & 313 & 1 & & & \\
7 & 293 & 14 & 14 & 320 & 5 & & & & & & \\
\hline
\end{tabular}

The data in each group was taken from different references, listed as following:

$\alpha$-pinene: Cocker et al. (2001a); Griffin et al. (1999); Hoffmann et al. (1997); Kamens et al. (1999); Offenberg et al. (2007); Pathak et al. (2007a, b); Presto et al., (2005); Presto and Donahue (2006); Saathoff et al. (2009); Warren et al. (2009); Yu et al. (1999).

Limonene: Saathoff et al. (2009); Sarwar et al. (2007); Chen and Hopke (2010).

$m$-xylene: Takekawa et al. (2003); Cocker et al. (2001b); Odum et al. (1996).

Table 3a. The unified temperature parameterized functions $\alpha(T)$ for mass stoichiometric coefficient $(\alpha)$.

\begin{tabular}{lll}
\hline species & $\alpha_{1}$ & $\alpha_{2}$ \\
\hline$\alpha$-pinene & $\alpha_{1}=0.03315+\frac{13.377}{T-179.17}$ & $\alpha_{2}=\frac{6186.77}{T}+0.0659 \cdot T-40.296$ \\
limonene & $\alpha_{1}=2.018 e^{-3} \cdot T-0.3114$ & $\alpha_{2}=3.32-0.0106 \cdot T$ \\
$m$-xylene & $\alpha_{1}=4.912 e^{-5} \cdot T^{3}+12.67 \cdot T-0.0432 \cdot T^{2}-1237.702$ & $\alpha_{2}=8.180 e^{-5} \cdot T^{3}+21.18 \cdot T-0.0721 \cdot T^{2}-2071.922$ \\
\hline
\end{tabular}

Table 3b. The unified temperature parameterized functions $K(T)$ for gas-particle partitioning coefficient $(K)$.

\begin{tabular}{lll}
\hline species & $K_{1}$ & $K_{2}$ \\
\hline$\alpha$-pinene & $K_{1}=\frac{2.419}{3.658 e^{-4} \cdot T^{2}-0.181 \cdot T+22.35}$ & $K_{2}=\frac{4605.54}{121.175 \cdot T^{2}-58611.81 \cdot T+7319862.5}$ \\
limonene & $K_{1}=\frac{1000.55}{T-245.94}-16.7212$ & $K_{2}=\frac{227.58}{T-228.84}-1.0581$ \\
$m$-xylene & $K_{1}=2.675 e^{-3} \cdot T^{3}+691.21 \cdot T-2.356 \cdot T^{2}-67553.914$ & $K_{2}=5.952 e^{-6} \cdot T^{3}+1.55 \cdot T-5.256 e^{-3} \cdot T^{2}-151.349$ \\
\hline
\end{tabular}

aerosols in these experiments, and the $\mathrm{RH}$ was lower than $10 \%$ in most of cases. For $m$-xylene, the oxidant was $\mathrm{OH}$ radical, and the concentrations of $m$-xylene were in the range of 256 to $2114 \mu \mathrm{g} \mathrm{m}^{-3}$ (average: $1123 \mu \mathrm{g} \mathrm{m}^{-3}$ ). Sulfate seed aerosols were used in the experiments, and the RH was low $(<10 \%)$ in more than $75 \%$ of the experiments.

We further validated the derived $\alpha(T)$ and $K(T)$ by comparing the modeled results against available chamber experiments. Original SORGAM model and SORGAM-TIN were employed to simulate the SOA formed by $\alpha$-pinene, limonene and $m$-xylene, and the SOA by isoprene was also tested in the SORGAM-TIN.

In Fig. 4, the original model usually overestimates SOA concentration for all three precursors; but for these precursors the simulated SOA concentrations are closest to the observation data by SORGAM-TIN. Due to fewer data points available from only one experiment at a fixed temperature, the simulation of isoprene SOA performs very well.

To evaluate the performance of each model quantitatively, normalized mean bias (NMB) and normalized mean errors
(NME) were calculated by the following formulae:

$$
\mathrm{NMB}=\frac{\sum_{i=1}^{n}\left(C_{i}^{\mathrm{s}}-C_{i}^{\mathrm{o}}\right)}{\sum_{i=1}^{n} C_{i}^{\mathrm{o}}} \times 100 \%, \mathrm{NME}=\frac{\sum_{i=1}^{n}\left|C_{i}^{\mathrm{s}}-C_{i}^{\mathrm{o}}\right|}{\sum_{i=1}^{n} C_{i}^{\mathrm{o}}} \times 100 \%,
$$

where $C_{i}^{\mathrm{s}}$ and $C_{i}^{\mathrm{o}}$ are simulated and observed SOA concentration respectively.

The statistical results of NMB, NME and correlation coefficient (CORREL) calculated for the two models are listed in Table 4. For $\alpha$-pinene, the NME decreased from $74.1 \%$ for the original SORGAM to $27.2 \%$ for SORGAM-TIN. For limonene, the simulation result of the original model is good, with a NME of $20.6 \%$, while it improved with the optimized functions in the SORGAM-TIN, with a NME of $17.3 \%$. The optimized functions dramatically reduce the NME for $m$ xylene $(17.4 \%)$, compared to the result of the original model with a NME of $70 \%$. The result for isoprene SOA with the optimized parameters indicates its good performance. For all precursors, the correlation coefficients between observed and 

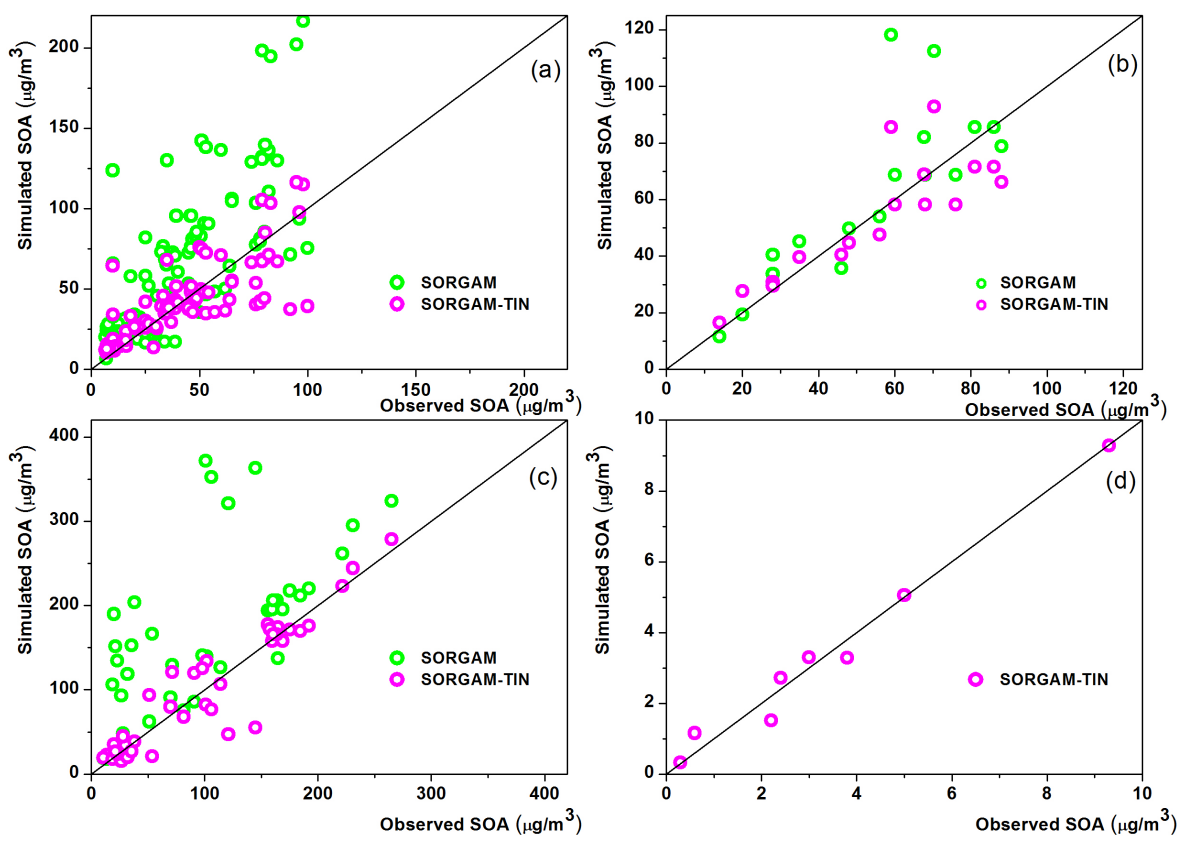

Fig. 4. Comparisons of observed chamber experiment data (x-axis) with original SORGAM (green) and SORGAM-TIN (pink) simulations (y-axis) for (a) $\alpha$-pinene, (b) limonene, (c) $m$-xylene, and (d) isoprene.

Table 4. Evaluation of box model simulations with SORGAM and SORGAM-TIN for all species.

\begin{tabular}{llrr}
\hline Species & & SORGAM & SORGAM-TIN \\
\hline$\alpha$-pinene & NMB & $66.5 \%$ & $-0.9 \%$ \\
& NME & $74.1 \%$ & $27.2 \%$ \\
& CORREL & 0.770 & 0.802 \\
\hline limonene & NMB & $13.8 \%$ & $-2.4 \%$ \\
& NME & $20.6 \%$ & $17.3 \%$ \\
& CORREL & 0.802 & 0.842 \\
\hline$m$-xylene & NMB & $68.0 \%$ & $-0.3 \%$ \\
& NME & $70.0 \%$ & $17.4 \%$ \\
& CORREL & 0.640 & 0.933 \\
\hline isoprene & NMB & - & $0.2 \%$ \\
& NME & - & $9.2 \%$ \\
& CORREL & - & 0.989 \\
\hline
\end{tabular}

simulated values for the optimized functions are higher than those for the original model ( $R$ as 0.802 vs. 0.770 for $\alpha$ pinene; 0.842 vs. 0.802 for limonene; 0.933 vs. 0.640 for $m$-xylene). According to the results in Table 4, the simulated SOA concentration by the SORGAM-TIN agreed well with observations in chamber experiments.

We took $\alpha$-pinene as an example to show the influence of temperature. In Fig. 5, the temperature test cases are computed with $\pm 5 \mathrm{~K}$. Although the temperature influences both reaction rate and partitioning coefficient, it can be seen that simulated SOA concentrations increased with decreasing temperature, with changes of $+9 \%$ and $-6 \%$ in average at low and high temperatures, respectively. It is noticed that when the mass of SOA is low, the influence of temperature is higher, because with a low $M_{0}$ a small change of SOA concentration may lead to a large rate of change.

\subsection{The application of SORGAM-TIN in EURAD-IM}

\subsubsection{The campaign in Cabauw}

Within the frame of the EUCAARI project, a comprehensive field campaign - IMPACT (Intensive Measurement Period At Cabauw Tower) campaign - was conducted in May 2008 in Cabauw, the Netherlands. The measurement site, namely, the Cabauw Experimental Site for Atmospheric Research (CE$\mathrm{SAR})$, is located in the center of the Netherlands $\left(51.972^{\circ} \mathrm{N}\right.$, 4.926 $\left.{ }^{\circ} \mathrm{E}\right)$.

During the campaign, the temperature in Cabauw was between 283 and $298 \mathrm{~K}$, with the average temperature higher in the first half part than in the second part. The prevailing wind was easterly wind of continental origin induced by an anticyclone regime till 15 May and changed to northerly wind during 15-17 May, due to the passage of a frontal system. Strong precipitation occurred on 16 and 17 May, and another precipitation event took place at the end of the month.

More details about the Cabauw measurements in particular the synoptic conditions can be found in Hamburger et al. (2011). In this work, the observed SOA concentrations were estimated by the summed concentrations of the 


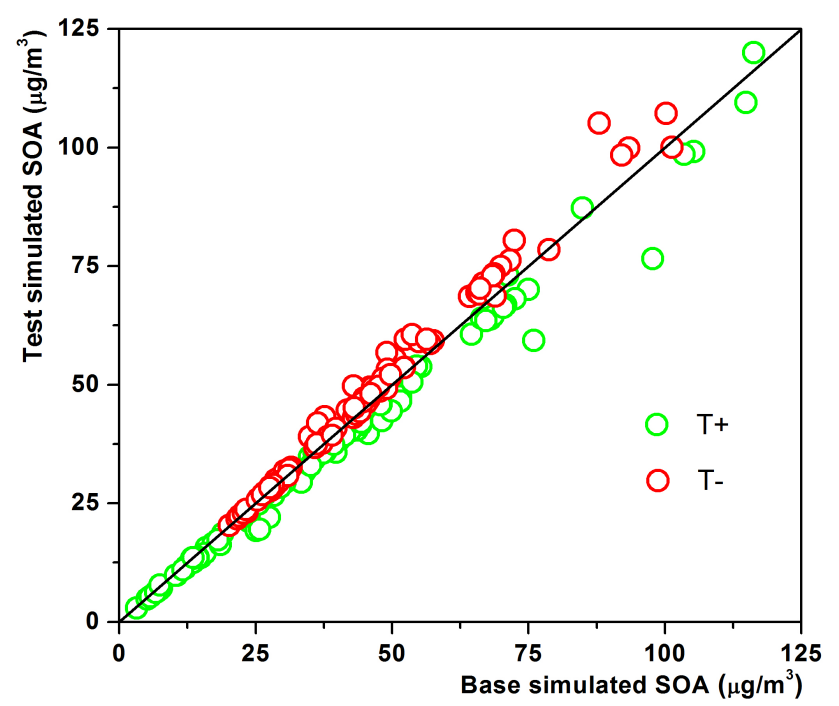

Fig. 5. Box model sensitivity study on temperature for SOA mass produced from $\alpha$-pinene The base case is the same as the final result in Fig. 4, and the test cases are calculated with $5 \mathrm{~K}$ higher $(T+)$ and $5 \mathrm{~K}$ lower $(T-)$ temperature.

semi-volatile oxygenated organic aerosol (SV-OOA) and low-volatile OOA (LV-OOA) factors from AMS measurements (Mensah et al., 2012) followed by a positive matrix factorization (PMF) analysis (Docherty et al., 2008). In previous studies, Docherty et al. (2008) calculated the concentration of SOA by some widely used methods, such as EC and $\mathrm{CO}$ tracer methods, water soluble organic carbon content, chemical mass balance of organic molecular markers and PMF results from AMS data. The comparison of predicted SOA/OA ratios by these methods showed that the ratio obtained by the AMS (aerosol mass spectrometer)-PMF method was the median and very close to the average of the results of these methods. Therefore the results derived from the AMS-PMF method were considered to be a good observational estimation of SOA concentrations. However, the AMS-PMF method also contains two major uncertainties: one is the accuracy of the AMS measurement itself, which is mainly limited by the uncertainty of the applied collection efficiency (Canagaratna et al., 2007); the other is the uncertainty of the subsequent PMF analysis (Ulbrich et al., 2009). With respect to the Caubauw dataset, the applied collection efficiency of AMS measurement was validated against a SMPS instrument; the inorganic and organic compositions measured by AMS were inter-compared against MARGA and TD-PTR-MS, respectively (Mensah et al., 2012). In general, reasonable good agreements between AMS and MARGA, and between AMS and TD-PTR-MS were achieved.

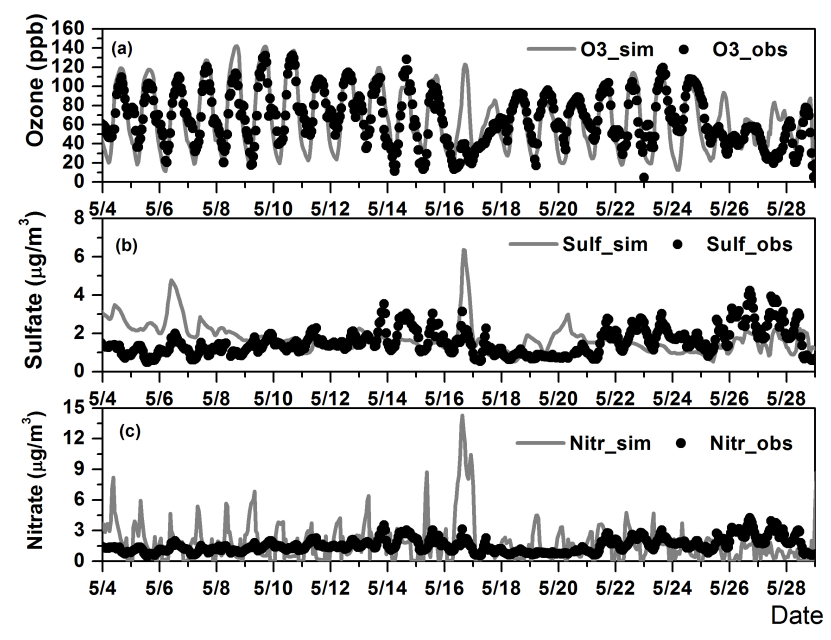

Fig. 6. Time series of observed (black dots) and simulated (gray line) (a) ozone, (b) sulfate and (c) nitrate in Cabauw May 2008.

\subsubsection{EURAD-IM modeling system}

The EURAD-IM used in this study simulates the physical and chemical evolution of trace gases and aerosols in the troposphere and lower stratosphere. The meteorological fields needed by EURAD-IM were computed using MM5 version 3 (Grell et al., 1994). The RACM-MIM-GK chemical mechanism (Stockwell et al., 1997; Geiger et al., 2003; Karl et al., 2006; Lu et al., 2012) was used to describe the atmospheric gas phase chemistry. The aerosol module used is MADE containing SORGAM. The spatial distribution of anthropogenic emissions was derived from a high-resolution emission inventory (Kuenen et al., 2011) for the year 2007 based on the TNO emission inventory for 2005 (Denier van der Gon et al., 2010). Biogenic emissions were taken from Symeonidis et al. (2008) or calculated using the parameterizations of Lamb et al. (1993) for regions where the data is not available in Symenoidis et al. (2008). A horizontal resolution of $45 \mathrm{~km}$ was chosen, the atmosphere was divided into 23 vertical layers, and the height of the near surface layer was $35 \mathrm{~m}$.

Figure 6 shows the comparisons of observed and simulated ozone, sulfate and nitrate for Cabauw in May 2008. The simulated results can capture the trends of the three species, with a NME of $29.2 \%$ for ozone, $42.0 \%$ for sulfate and $51.0 \%$ for nitrate. The large errors on 16 May might be caused by a failure to simulate the precipitation intensity and/or impact of wet removal at Cabauw. In general, the good performance indicates that EURAD-IM does well in the simulation of the meteorological and photochemical processes for inorganic species. 

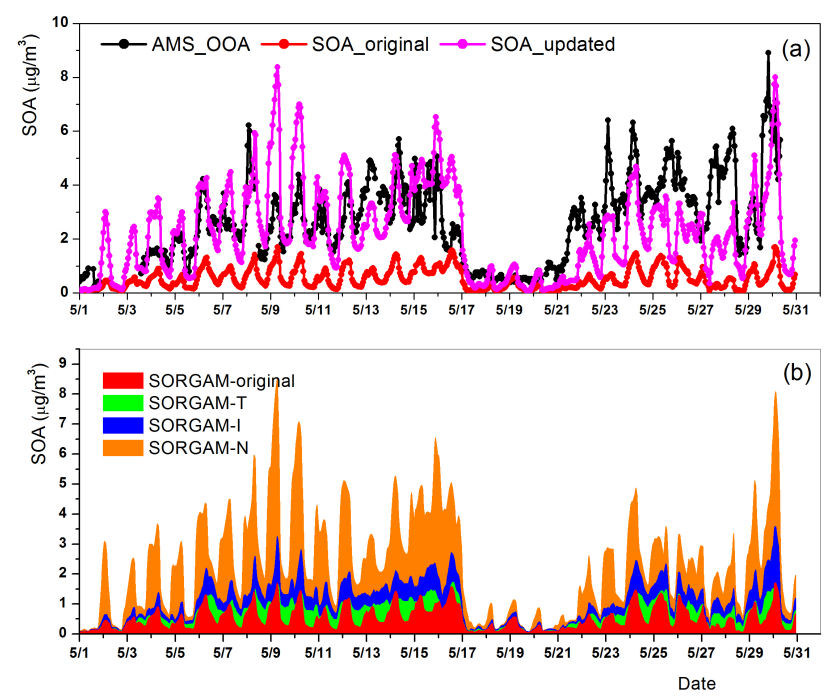

Fig. 7. Time series of AMS_OOA and simulated SOA concentration in Cabauw 2008. (a) Black: observation; red: simulation results of original SORGAM; pink: results of SORGAM-TIN. (b) Green: increased SOA concentration by the temperature functions; blue: increased SOA concentration by isoprene; orange: increased SOA concentration by $\mathrm{NO}_{3}$ chemical pathways.

\subsubsection{The simulation of SOA with SORGAM-TIN in Cabauw}

Comparisons of simulated SOA concentrations by both the SORGAM and SORGAM-TIN and the observed SOA concentrations as represented by the sum of LV-OOA and SVOOA from AMS measurements are shown in Fig. 7. In Fig. 7a, the observed SOA concentration is strongly underestimated by SORGAM, while it is in general reasonably reproduced by SORGAM-TIN.

Following the division of the generic synoptic system as discussed in Hamburger et al. (2011) the modelmeasurement inter-comparisons are further studied for two selected periods: (1) the first half of May (1-15 May), which was controlled by subsiding air masses due to an anticyclone event, and (2) the second half of May (18-31 May), which was dominated by a westerly frontal passage. As mentioned above, precipitation occurred on 16 and 17 May.

The Benelux states always experienced the most serious air pollution over Europe in both periods as characterized by the airborne measurements and ground measurements at Caubaw (Hamburger et al., 2011). Interestingly, the observed SOA concentrations were much better reproduced by SORGAM-TIN for the first period than for the second period. The difference between these two periods was that the air was quite stagnant in the first period while constant westerly inflow took place during the second period. Additionally, the EURAD-IM model also overestimated the temperature at the second period. Therefore, an underestimation of the observed SOA concentration in the second period may be attributed to deficits of the transport term or temperature corrections of $K$ and $\alpha$. In the first period, apart from the general good agreement, the SORGAM-TIN strongly overestimated the observed SOA concentrations on 9 May. Another strong overestimation of SOA by SORGAM-TIN for 16 May can be attributed to a general failure of the EURADIM system to simulate time, location, and intensity of precipitation. This general failure was also found in the large model-measurement discrepancy of $\mathrm{O}_{3}$, sulfate and nitrate, as discussed above (Fig. 6). However, the reason for the large discrepancy on 9 May is probably due to errors of the SORGAM-N framework since the other parameters were well simulated in the EURAD-IM system.

To separate the contribution of the newly added SOA parameterizations, a cumulative plot of the SOA concentrations modeled by the individual updates (Table 5 to summarize the sensitivity studies tested with the EURAD-IM system) is shown in Fig. $7 b$.

The original SORGAM can only predict $20 \%$ of the observed SOA concentration. The application of both $\alpha(T)$ and $K(T)$ enhanced the simulated SOA concentration up to $27 \%$ of the observation, with an increment of $7 \%$. Moreover, the addition of isoprene SOA further increased the SOA concentration by $15 \%$ of the observation on average. Lastly, including $\mathrm{NO}_{3}$ oxidation as $\mathrm{SOA}$ formation pathways leads to an average increment of SOA by $32 \%$ of the observation. Overall, the modeled SOA concentration by SORGAM-TIN on average reproduced $88 \%$ of the observation.

Figure 8 further shows the averaged diurnal variation of the observed and modeled SOA concentration by SORGAM, SORGAM-TIN and the three important mechanistic updates as summarized in Table 5, including the effect of each improvement. The temperature functions usually increase the SOA concentration in the daytime and even decrease the concentration during the early morning. Adding isoprene does not change the diurnal variation of the SOA concentration, but increases the concentration on average. Employing $\mathrm{NO}_{3}$ pathways immensely increases the SOA concentration during nighttime since the $\mathrm{NO}_{3}$ chemistry often becomes significant at nighttime due to the small NO concentration and missing insolation.

The diurnal variation simulated by the SORGAM-TIN is reasonable during nighttime. In the afternoon the SORGAMTIN still strongly underestimates observation. This may indicate that functionalization reactions in successive oxidation processes are playing an important role (Murphy et al., 2012) or the thermodynamic equilibrium assumption is not applicable as discussed by Perraud et al. (2012). The difference between the real atmosphere and experimental conditions for the data in the laboratory studies used for parameterization surely contributes to deficiencies. Furthermore, as we now recognized, the afternoon $\mathrm{OH}$ concentrations might be strongly underestimated by current models at rural or suburban conditions (Hofzumahaus et al., 2009; Lu et al., 2012, 2013). In addition, chamber studies with mixed 


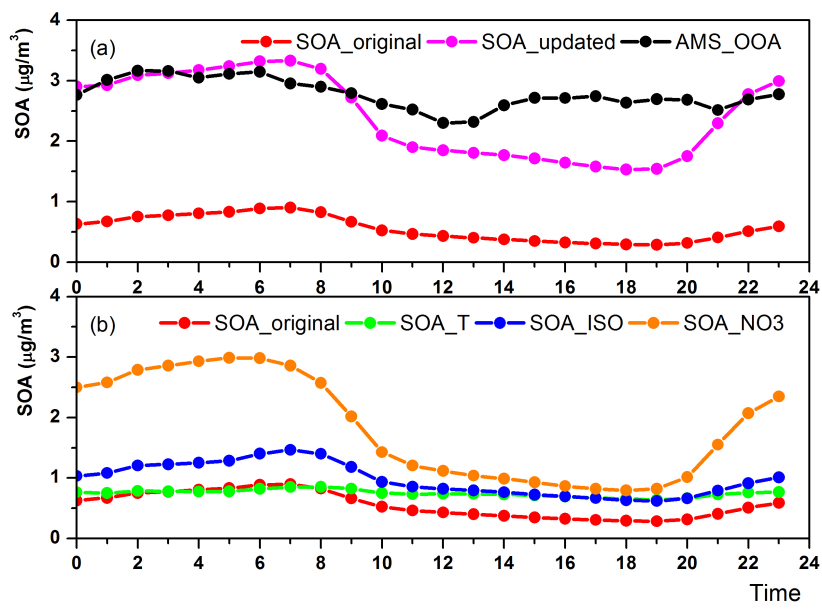

Fig. 8. Mean diurnal profiles of observed and modeled SOA concentrations in Cabauw from 5-29 May 2008. (a) Black: observation; red: simulation results of original SORGAM; pink: results of the updated SOA module. (b) Green: original SORGAM with temperature functions; blue: original SORGAM with isoprene; orange: original SORGAM with $\mathrm{NO}_{3}$ chemical pathways.

anthropogenic and biogenic precursors showed that anthropogenic SOA could promote the formation and persistence of biogenic SOA (Emanuelsson et al., 2013). Underestimated $\mathrm{OH}$ concentrations and missing interaction processes of anthropogenic and biogenic SOA could thus at least partially explain the underestimated SOA concentration in the afternoon.

We compare this study to other similar reports regarding the SOA simulation in Europe. The simulation with the CHIMERE model in Paris, spring 2007, was reported by Sciare et al. (2010), who found that the SOA was underestimated possibly due to missing potential sources of SOA in the model such as the aging of POA and oligomerization. Couvidat et al. (2012) simulated the SOA formation from isoprene oxidation with two sets of parameterizations (Henze and Seinfeld, 2006; Couvidat and Seigneur, 2011), and found out that the latter (Couvidat and Seigneur, 2011) calculated higher concentrations of isoprene SOA than the former (Henze and Seinfeld, 2006). The former is currently widely used in different CTMs and may underestimate isoprene produced SOA masses. Bergström et al. (2012) used the EMEP model with VBS method to simulate long-term OC (organic carbon) over Europe, covering 2002-2007. Different VBS schemes were employed, and the results indicated that considering aging of POA and primary emissions of semi-volatile components could significantly increase the simulated SOA concentrations. By comparing to these other model-measurement comparisons, we recognized that the missing of aerosol aging processes, the missing oligomerization process, the missing contributions from primary emitted semi-volatile organic compounds (SVOCs) and the parameterization of isoprene SOA formation process (e.g., the major
Table 5. The performance of adjusted models.

\begin{tabular}{lcc}
\hline & $\begin{array}{c}\text { Simulations/ } \\
\text { observation }\end{array}$ & $\begin{array}{c}\text { Simulations/ } \\
\text { original simulation }\end{array}$ \\
\hline Original SORGAM & 0.20 & 1.00 \\
SORGAM-T & 0.27 & 1.35 \\
SORGAM-I & 0.35 & 1.75 \\
SORGAM-N & 0.52 & 2.60 \\
SORGAM-TIN & 0.88 & 4.40 \\
\hline
\end{tabular}

SOA products were identified as 2-methyltetrols in both laboratory and field studies, cf. Claeys et al., 2004; Fu et al., 2010) could be possible reasons for the afternoon SOA underestimations with SORGAM-TIN as well.

Overall the normalized mean error for the updated model in this period was $32.7 \%$, which is similar to the results in other studies by PMCAMx (Tsimpidi et al., 2010; Murphy et al., 2010), and much better than the NME of $80.1 \%$ by the original SORGAM

\section{Conclusions}

As a continuous effort of the EURAD-IM development, we extensively updated the SORGAM module in EURAD-IM in this study. The new module, SORGAM-TIN, received three major modifications: (1) temperature dependent functions of SOA yields, (2) photo oxidation products from isoprene and (3) $\mathrm{NO}_{3}$ initiated oxidation products from biogenic VOCs. To derive the temperature dependent functions of SOA yields, we summarized the recently published chamber experimental results for $\alpha$-pinene, limonene and $m$-xylene and set them into a series of temperature interval defined bins. The optimization software Lsqnonlin, Eureqa and N12sol were employed to deduce temperature dependent functions in three steps through nonlinear optimizations. In addition, the influences of relative humidity, temperature and contributions of anthropogenic VOCs to SOA formation were also considered. However, they only show marginal contributions to SOA simulations. The SORGAMTIN was shown to perform well in reproducing chamber experiments, with normalized mean errors of less than $30 \%$ in the box model. In contrast, the normalized mean error for the original SORGAM module is much worse especially for $\alpha$-pinene $(\mathrm{NME}=74 \%)$ and $m$-xylene $(\mathrm{NME}=70 \%)$.

Both SORGAM-TIN and SORGAM were further tested in the chemical transport model EURAD-IM and model results were compared to ambient observations at a rural site near Rotterdam, during Cabauw measurements in May 2008. The observed SOA concentrations were represented by summed OOA concentrations extracted from measurement results of an AMS instrument. The original SORGAM model strongly underestimated the observed concentration of SOA explaining only $20 \%$ of the observed concentrations. In contrast, 
the simulated SOA concentration with SORGAM-TIN could explain on average $88 \%$ of the observed SOA. The largely improved model results were mainly contributed to the implementation of temperature dependent $\alpha(T)$ and $K(T)$, the photo oxidation of isoprene and the $\mathrm{NO}_{3}$ initiated oxidation of biogenic VOCs, contributing 7, 15 and $32 \%$ of the observations, respectively.

However, there are still significant daytime measurementmodel discrepancies for SORGAM-TIN, especially for the afternoon hours. Details of the remaining discrepancies remain speculative and still need to be explored in future, when more laboratory and field data are available. In principle, in SORGAM-TIN, considerations of aerosol aging processes (Rudich et al., 2007; Donahue et al., 2012) are missing, and the assumption of all SOA being formed in thermodynamic equilibrium processes may be wrong (Perraud et al., 2012). In addition, due to a general underestimation of ambient $\mathrm{OH}$ concentrations reported for forest, rural and suburban areas (Stone et al., 2012), the production rates of the oxidation products during daytime are uncertain as well. Moreover, according to our model tests performed herein, the reactions of the $\mathrm{NO}_{3}$ radical with biogenic VOCs are found to be important for SOA formation. More laboratory and field experiments on this aspect are therefore required in the future. Oligomerization processes, mixed precursors, multiphase and multigenerational reactions should be included in future work as well.

Acknowledgements. We acknowledge financial support by the National Natural Science Foundation of China (Major Program: 21190052\&Innovative Research Group: 41121004), Strategic Priority Research Program of the Chinese Academy of Sciences (grant no. XDB05010500) and by EU-project CityZen (grant no. 212095) and PEGASOS (grant no. 265307). Discussions with M. Zheng are gratefully acknowledged.

The service charges for this open access publication have been covered by a Research Centre of the Helmholtz Association.

Edited by: H. Su

\section{References}

Ackermann, I. J., Hass, H., Memmesheimer, M., Ebel, A., Binkowski, F. S., and Shankar, U.: Modal aerosol dynamics model for Europe: Development and first applications, Atmos. Environ., 32, 2981-2999, 1998.

Bergström, R., Denier van der Gon, H. A. C., Prévôt, A. S. H., Yttri, K. E., and Simpson, D.: Modelling of organic aerosols over Europe (2002-2007) using a volatility basis set (VBS) framework: application of different assumptions regarding the formation of secondary organic aerosol, Atmos. Chem. Phys., 12, 8499-8527, doi:10.5194/acp-12-8499-2012, 2012.

Canagaratna, M. R., Jayne, J. T., Jimenez, J. L., Allan, J. D., Alfarra, M. R., Zhang, Q., Onasch, T. B., Drewnick, F., Coe, H.,
Middlebrook, A., Delia, A., Williams, L. R., Trimborn, A. M., Northway, M. J., DeCarlo, P. F., Kolb, C. E., Davidovits, P., and Worsnop, D. R.: Chemical and microphysical characterization of ambient aerosols with the aerodyne aerosol mass spectrometer, Mass Spectrom. Rev., 26, 185-222, 2007.

Cappa, C. D., Zhang, X., Loza, C. L., Craven, J. S., Yee, L. D., and Seinfeld, J. H.: Application of the Statistical Oxidation Model (SOM) to Secondary Organic Aerosol formation from photooxidation of C12 alkanes, Atmos. Chem. Phys., 13, 1591-1606, doi:10.5194/acp-13-1591-2013, 2013.

Carlton, A. G., Bhave, P. V., Napelenok, S. L., Edney, E. D., Sarwar, G., Pinder, R. W., Pouliot, G. A., and Houyoux, M.: Model Representation of Secondary Organic Aerosol in CMAQv4.7, Environ. Sci. Technol., 44, 8553-8560, 2010.

Chen, X. and Hopke, P. K.: A chamber study of secondary organic aerosol formation by limonene ozonolysis, Indoor Air, 20, 320328, 2010.

Chervenkov, H. and Jakobs, H.: Dust storm simulation with regional air quality model - Problems and results, Atmos. Environ., 45, 3965-3976, 2011.

Chhabra, P. S., Flagan, R. C., and Seinfeld, J. H.: Elemental analysis of chamber organic aerosol using an aerodyne high-resolution aerosol mass spectrometer, Atmos. Chem. Phys., 10, 4111-4131, doi:10.5194/acp-10-4111-2010, 2010.

Chung, S. H. and Seinfeld, J. H.: Global distribution and climate forcing of carbonaceous aerosols, J. Geophys. Res.-Atmos., 107, 4407, doi:10.1029/2001JD001397, 2002.

Claeys, M., Graham, B., Vas, G., Wang, W., Vermeylen, R., Pashynska, V., Cafmeyer, J., Guyon, P., Andreae, M. O., Artaxo, P., and Maenhaut, W.: Formation of secondary organic aerosols through photooxidation of isoprene, Science, 303, 1173-1176, 2004.

Cocker, D. R., Clegg, S. L., Flagan, R. C., and Seinfeld, J. H.: The effect of water on gas-particle partitioning of secondary organic aerosol. Part I: alpha-pinene/ozone system, Atmos. Environ., 35, 6049-6072, 2001a.

Cocker, D. R., Mader, B. T., Kalberer, M., Flagan, R. C., and Seinfeld, J. H.: The effect of water on gas-particle partitioning of secondary organic aerosol: II. m-xylene and 1, 3, 5trimethylbenzene photooxidation systems, Atmos. Environ., 35, 6073-6085, 2001b.

Colette, A., Granier, C., Hodnebrog, Ø., Jakobs, H., Maurizi, A., Nyiri, A., Bessagnet, B., D’Angiola, A., D'Isidoro, M., Gauss, M., Meleux, F., Memmesheimer, M., Mieville, A., Rouil, L., Russo, F., Solberg, S., Stordal, F., and Tampieri, F.: Air quality trends in Europe over the past decade: a first multi-model assessment, Atmos. Chem. Phys., 11, 11657-11678, doi:10.5194/acp11-11657-2011, 2011.

Couvidat, F. and Seigneur, C.: Modeling secondary organic aerosol formation from isoprene oxidation under dry and humid conditions, Atmos. Chem. Phys., 11, 893-909, doi:10.5194/acp-11893-2011, 2011.

Couvidat, F., Debry, E., Sartelet, K., and Seigneur, C.: A hydrophilic/hydrophobic organic ((HO)-O-2) aerosol model: Development, evaluation and sensitivity analysis, J. Geophys. Res.Atmos., 117, D10304, doi:10.1029/2011JD017214, 2012.

Denier van der Gon, H., Visschedijk, A., Kuenen, J., van der Brugh, H., Dröge, R., and Schaap, M.: High resolution European emission grids for anthropogenic sources for the years 2003-2007, EGU 2010 special session Monitoring Atmospheric Composi- 
tion and Climate, Geophys. Res. Abstracts, Vol. 12, EGU201010800-1, 2010.

Dennis, J. E., Gay, D. M. and Welsch, R. E.: ALGORITHM 573 NL2SOL - AN ADAPTIVE NON-LINEAR LEAST-SQUARES ALGORITHM E4, Acm T. Math. Software., 7, 369-383, 1981.

Docherty, K. S., Stone, E. A., Ulbrich, I. M., DeCarlo, P. F., Snyder, D. C., Schauer, J. J., Peltier, R. E., Weber, R. J., Murphy, S. M., Seinfeld, J. H., Grover, B. D., Eatough, D. J., and Jimenez, J. L.: Apportionment of Primary and Secondary Organic Aerosols in Southern California during the 2005 Study of Organic Aerosols in Riverside (SOAR-1), Environ. Sci. Technol., 42, 7655-7662, 2008.

Dommen, J., Metzger, A., Duplissy, J., Kalberer, M., Alfarra, M. R., Gascho, A., Weingartner, E., Prevot, A. S. H., Verheggen, B., and Baltensperger, U.: Laboratory observation of oligomers in the aerosol from isoprene/ $\mathrm{NO}(\mathrm{x})$ photooxidation, Geophys. Res. Lett., 33, L13805, doi:10.1029/2006gl026523, 2006.

Donahue, N. M., Robinson, A. L., Stanier, C. O., and Pandis, S. N.: Coupled partitioning, dilution, and chemical aging of semivolatile organics, Environ. Sci. Technol., 40, 2635-2643, 2006.

Donahue, N. M., Henry, K. M., Mentel, T. F., Kiendler-Scharr, A., Spindler, C., Bohn, B., Brauers, T., Dorn, H. P., Fuchs, H., Tillmann, R., Wahner, A., Saathoff, H., Naumann, K. H., Mohler, O., Leisner, T., Muller, L., Reinnig, M. C., Hoffmann, T., Salo, K., Hallquist, M., Frosch, M., Bilde, M., Tritscher, T., Barmet, P., Praplan, A. P., DeCarlo, P. F., Dommen, J., Prevot, A. S. H., and Baltensperger, U.: Aging of biogenic secondary organic aerosol via gas-phase $\mathrm{OH}$ radical reactions, P. Natl. Acad. Sci. USA, 109, 13503-13508, 2012.

Elbern, H., Strunk, A., Schmidt, H., and Talagrand, O.: Emission rate and chemical state estimation by 4-dimensional variational inversion, Atmos. Chem. Phys., 7, 3749-3769, doi:10.5194/acp7-3749-2007, 2007.

Emanuelsson, E. U., Hallquist, M., Kristensen, K., Glasius, M., Bohn, B., Fuchs, H., Kammer, B., Kiendler-Scharr, A., Nehr, S., Rubach, F., Tillmann, R., Wahner, A., Wu, H.-C., and Mentel, Th. F.: Formation of anthropogenic secondary organic aerosol (SOA) and its influence on biogenic SOA properties, Atmos. Chem. Phys., 13, 2837-2855, doi:10.5194/acp-13-2837-2013, 2013.

Fry, J. L., Kiendler-Scharr, A., Rollins, A. W., Wooldridge, P. J., Brown, S. S., Fuchs, H., Dubé, W., Mensah, A., dal Maso, M., Tillmann, R., Dorn, H.-P., Brauers, T., and Cohen, R. C.: Organic nitrate and secondary organic aerosol yield from $\mathrm{NO}_{3}$ oxidation of $\beta$-pinene evaluated using a gas-phase kinetics/aerosol partitioning model, Atmos. Chem. Phys., 9, 14311449, doi:10.5194/acp-9-1431-2009, 2009.

Fry, J. L., Kiendler-Scharr, A., Rollins, A. W., Brauers, T., Brown, S. S., Dorn, H.-P., Dubé, W. P., Fuchs, H., Mensah, A., Rohrer, F., Tillmann, R., Wahner, A., Wooldridge, P. J., and Cohen, R. C.: SOA from limonene: role of $\mathrm{NO}_{3}$ in its generation and degradation, Atmos. Chem. Phys., 11, 3879-3894, doi:10.5194/acp-113879-2011, 2011.

Fu, P. Q., Kawamura, K., Pavuluri, C. M., Swaminathan, T., and Chen, J.: Molecular characterization of urban organic aerosol in tropical India: contributions of primary emissions and secondary photooxidation, Atmos. Chem. Phys., 10, 2663-2689, doi:10.5194/acp-10-2663-2010, 2010.
Fu, T.-M., Jacob, D. J., Wittrock, F., Burrows, J. P., Vrekoussis, M., and Henze, D. K.: Global budgets of atmospheric glyoxal and methylglyoxal, and implications for formation of secondary organic aerosols, J. Geophys. Res.-Atmos., 113, D15303, doi:10.1029/2007jd009505, 2008.

Geiger, H., Barnes, I., Bejan, J., Benter, T. and Spittler, M.: The tropospheric degradation of isoprene: an updated module for the regional atmospheric chemistry mechanism, Atmos. Environ., 37, 1503-1519, 2003

Grell, G. A., Dudhia, J., and Stauffer, D. R.: A description of the fifth generation Penn State/NCAR mesoscale model (MM5); NCAR TN-398+IA, technical report, National Center for Atmospheric Research, Boulder, Colorado, 1994.

Griffin, R. J., Cocker, D. R., Flagan, R. C., and Seinfeld, J. H.: Organic aerosol formation from the oxidation of biogenic hydrocarbons, J. Geophys. Res.-Atmos., 104, 3555-3567, 1999.

Guenther, A., Zimmerman, P., Klinger, L., Greenberg, J., Ennis, C., Davis, K., Pollock, W., Westberg, H., Allwine, G., and Geron, C.: Estimates of regional natural volatile organic compound fluxes from enclosure and ambient measurements, J. Geophys. Res.Atmos., 101, 1345-1359, 1996.

Guenther, A., Karl, T., Harley, P., Wiedinmyer, C., Palmer, P. I., and Geron, C.: Estimates of global terrestrial isoprene emissions using MEGAN (Model of Emissions of Gases and Aerosols from Nature), Atmos. Chem. Phys., 6, 3181-3210, doi:10.5194/acp-63181-2006, 2006.

Hallquist, M., Wenger, J. C., Baltensperger, U., Rudich, Y., Simpson, D., Claeys, M., Dommen, J., Donahue, N. M., George, C., Goldstein, A. H., Hamilton, J. F., Herrmann, H., Hoffmann, T., Iinuma, Y., Jang, M., Jenkin, M. E., Jimenez, J. L., Kiendler-Scharr, A., Maenhaut, W., McFiggans, G., Mentel, Th. F., Monod, A., Prévôt, A. S. H., Seinfeld, J. H., Surratt, J. D., Szmigielski, R., and Wildt, J.: The formation, properties and impact of secondary organic aerosol: current and emerging issues, Atmos. Chem. Phys., 9, 5155-5236, doi:10.5194/acp-9-51552009, 2009.

Hamburger, T., McMeeking, G., Minikin, A., Birmili, W., Dall'Osto, M., O'Dowd, C., Flentje, H., Henzing, B., Junninen, H., Kristensson, A., de Leeuw, G., Stohl, A., Burkhart, J. F., Coe, H., Krejci, R., and Petzold, A.: Overview of the synoptic and pollution situation over Europe during the EUCAARILONGREX field campaign, Atmos. Chem. Phys., 11, 10651082, doi:10.5194/acp-11-1065-2011, 2011.

Heald, C. L., Jacob, D. J., Park, R. J., Russell, L. M., Huebert, B. J., Seinfeld, J. H., Liao, H., and Weber, R. J.: A large organic aerosol source in the free troposphere missing from current models, Geophys. Res. Lett., 32, L18809, doi:10.1029/2005g1023831, 2005.

Henze, D. K. and Seinfeld, J. H.: Global secondary organic aerosol from isoprene oxidation, Geophys. Res. Lett., 33, L09812, doi:10.1029/2006g1025976, 2006.

Hoffmann, T., Odum, J. R., Bowman, F., Collins, D., Klockow, D., Flagan, R. C., and Seinfeld, J. H.: Formation of organic aerosols from the oxidation of biogenic hydrocarbons, J. Atmos. Chem., 26, 189-222, 1997.

Hofzumahaus, A., Rohrer, F., Lu, K. D., Bohn, B., Brauers, T., Chang, C. C., Fuchs, H., Holland, F., Kita, K., Kondo, Y., Li, X., Lou, S. R., Shao, M., Zeng, L. M., Wahner, A., and Zhang, Y. H.: Amplified Trace Gas Removal in the Troposphere, Science, 324, 1702-1704, 2009. 
Jimenez, J. L., Canagaratna, M. R., Donahue, N. M., Prevot, A. S. H., Zhang, Q., Kroll, J. H., DeCarlo, P. F., Allan, J. D., Coe, H., Ng, N. L., Aiken, A. C., Docherty, K. S., Ulbrich, I. M., Grieshop, A. P., Robinson, A. L., Duplissy, J., Smith, J. D., Wilson, K. R., Lanz, V. A., Hueglin, C., Sun, Y. L., Tian, J., Laaksonen, A., Raatikainen, T., Rautiainen, J., Vaattovaara, P., Ehn, M., Kulmala, M., Tomlinson, J. M., Collins, D. R., Cubison, M. J., Dunlea, E. J., Huffman, J. A., Onasch, T. B., Alfarra, M. R., Williams, P. I., Bower, K., Kondo, Y., Schneider, J., Drewnick, F., Borrmann, S., Weimer, S., Demerjian, K., Salcedo, D., Cottrell, L., Griffin, R., Takami, A., Miyoshi, T., Hatakeyama, S., Shimono, A., Sun, J. Y., Zhang, Y. M., Dzepina, K., Kimmel, J. R., Sueper, D., Jayne, J. T., Herndon, S. C., Trimborn, A. M., Williams, L. R., Wood, E. C., Middlebrook, A. M., Kolb, C. E., Baltensperger, U., and Worsnop, D. R.: Evolution of Organic Aerosols in the Atmosphere, Science, 326, 1525-1529, 2009.

Jonsson, Å. M., Hallquist, M., and Ljungström, E.: The effect of temperature and water on secondary organic aerosol formation from ozonolysis of limonene, $\Delta 3$-carene and $\alpha$-pinene, Atmos. Chem. Phys., 8, 6541-6549, doi:10.5194/acp-8-6541-2008, 2008.

Kamens, R., Jang, M., Chien, C. J., and Leach, K.: Aerosol formation from the reaction of alpha-pinene and ozone using a gasphase kinetics aerosol partitioning model, Environ. Sci. Technol., 33, 1430-1438, 1999.

Kamens, R. M., Zhang, H. F., Chen, E. H., Zhou, Y., Parikh, H. M., Wilson, R. L., Galloway, K. E., and Rosen, E. P.: Secondary organic aerosol formation from toluene in an atmospheric hydrocarbon mixture: Water and particle seed effects, Atmos. Environ., 45, 2324-2334, 2011.

Karl, M., Dorn, H. P., Holland, F., Koppmann, R., Poppe, D., Rupp, L., Schaub, A., and Wahner, A.: Product study of the reaction of $\mathrm{OH}$ radicals with isoprene in the atmosphere simulation chamber SAPHIR, J. Atmos. Chem., 55, 167-187, 2006.

Kavouras, I. G., Mihalopoulos, N., and Stephanou, E. G.: Formation of atmospheric particles from organic acids produced by forests, Nature, 395, 683-686, 1998.

Kesselmeier, J. and Staudt, M.: Biogenic volatile organic compounds (VOC): An overview on emission, physiology and ecology, J. Atmos. Chem., 33, 23-88, 1999.

Kleindienst, T. E., Lewandowski, M., Offenberg, J. H., Jaoui, M., and Edney, E. O.: The formation of secondary organic aerosol from the isoprene $+\mathrm{OH}$ reaction in the absence of $\mathrm{NO}_{\mathrm{x}}$, Atmos. Chem. Phys., 9, 6541-6558, doi:10.5194/acp-9-6541-2009, 2009.

Kroll, J. H., Ng, N. L., Murphy, S. M., Flagan, R. C., and Seinfeld, J. H.: Secondary organic aerosol formation from isoprene photooxidation, Environ. Sci. Technol., 40, 1869-1877, 2006.

Kuenen, J., Denier van der Gon, H., Visschedijk, A., and van der Brugh, H.: High resolution European emission inventory for the years 2003-2007, TNO report TNO-060-UT-2011-00588, Utrecht, 2011.

Lamb, B., Gay, D., Westberg, H., and Pierce, T.: A Biogenic Hydrocarbon Emission Inventory for the USA Using a Simple Forest Canopy Model, Atmos. Environ. Part A, 27, 1673-1690, 1993.

Lane, T. E., Donahue, N. M., and Pandis, S. N.: Simulating secondary organic aerosol formation using the volatility basis-set approach in a chemical transport model, Atmos. Environ., 42, 7439-7451, 2008.
Lu, K. D., Rohrer, F., Holland, F., Fuchs, H., Bohn, B., Brauers, T., Chang, C. C., Häseler, R., Hu, M., Kita, K., Kondo, Y., Li, X., Lou, S. R., Nehr, S., Shao, M., Zeng, L. M., Wahner, A., Zhang, Y. H., and Hofzumahaus, A.: Observation and modelling of $\mathrm{OH}$ and $\mathrm{HO}_{2}$ concentrations in the Pearl River Delta 2006: a missing $\mathrm{OH}$ source in a VOC rich atmosphere, Atmos. Chem. Phys., 12, 1541-1569, doi:10.5194/acp-12-1541-2012, 2012.

Lu, K. D., Hofzumahaus, A., Holland, F., Bohn, B., Brauers, T., Fuchs, H., Hu, M., Häseler, R., Kita, K., Kondo, Y., Li, X., Lou, S. R., Oebel, A., Shao, M., Zeng, L. M., Wahner, A., Zhu, T., Zhang, Y. H., and Rohrer, F.: Missing OH source in a suburban environment near Beijing: observed and modelled $\mathrm{OH}$ and $\mathrm{HO}_{2}$ concentrations in summer 2006, Atmos. Chem. Phys., 13, 10571080, doi:10.5194/acp-13-1057-2013, 2013.

Mensah, A. A., Holzinger, R., Otjes, R., Trimborn, A., Mentel, Th. F., ten Brink, H., Henzing, B., and Kiendler-Scharr, A.: Aerosol chemical composition at Cabauw, The Netherlands as observed in two intensive periods in May 2008 and March 2009, Atmos. Chem. Phys., 12, 4723-4742, doi:10.5194/acp-12-4723-2012, 2012.

Monteiro, A., Strunk, A., Carvalho, A., Tchepel, O., Miranda, A. I., Borrego, C., Saavedra, S., Rodriguez, A., Souto, J., Casares, J., Friese, E., and Elbern, H.: Investigating a high ozone episode in a rural mountain site, Environ. Pollut., 162, 176-189, 2012.

Murphy, B. N. and Pandis, S. N.: Exploring summertime organic aerosol formation in the eastern United States using a regionalscale budget approach and ambient measurements, J. Geophys. Res.-Atmos., 115, D24216, doi:10.1029/2010JD014418, 2010.

Murphy, B. N., Donahue, N. M., Fountoukis, C., Dall'Osto, M., O'Dowd, C., Kiendler-Scharr, A., and Pandis, S. N.: Functionalization and fragmentation during ambient organic aerosol aging: application of the 2-D volatility basis set to field studies, Atmos. Chem. Phys., 12, 10797-10816, doi:10.5194/acp-1210797-2012, 2012.

Naumann, K. H.: COSIMA - a computer program simulating the dynamics of fractal aerosols, J. Aerosol Sci., 34, 1371-1397, 2003.

Ng, N. L., Kwan, A. J., Surratt, J. D., Chan, A. W. H., Chhabra, P. S., Sorooshian, A., Pye, H. O. T., Crounse, J. D., Wennberg, P. O., Flagan, R. C., and Seinfeld, J. H.: Secondary organic aerosol (SOA) formation from reaction of isoprene with nitrate radicals $\left(\mathrm{NO}_{3}\right)$, Atmos. Chem. Phys., 8, 4117-4140, doi:10.5194/acp-84117-2008, 2008.

Odum, J. R., Hoffmann, T., Bowman, F., Collins, D., Flagan, R. C., and Seinfeld, J. H.: Gas/particle partitioning and secondary organic aerosol yields, Environ. Sci. Technol., 30, 2580-2585, 1996.

Odum, J. R., Jungkamp, T. P. W., Griffin, R. J., Flagan, R. C., and Seinfeld, J. H.: The atmospheric aerosol-forming potential of whole gasoline vapor, Science, 276, 96-99, 1997.

Offenberg, J. H., Lewis, C. W., Lewandowski, M., Jaoui, M., Kleindienst, T. E., and Edney, E. O.: Contributions of toluene and alpha-pinene to SOA formed in an irradiated toluene/alphapinene/NOx/air mixture: Comparison of results using C-14 content and SOA organic tracer methods, Environ. Sci. Technol., 41, 3972-3976, 2007.

Pandis, S. N., Paulson, S. E., Seinfeld, J. H., and Flagan, R. C.: Aerosol formation in the photooxidation of isoprene and betapinene, Atmos. Environ. A, 25, 997-1008, 1991. 
Pankow, J. F.: Review and comparative-analysis of the theories on partitioning between the gas and aerosol particulate phases in the atmosphere, Atmos. Environ., 21, 2275-2283, 1987.

Pathak, R. K., Presto, A. A., Lane, T. E., Stanier, C. O., Donahue, N. M., and Pandis, S. N.: Ozonolysis of a-pinene: parameterization of secondary organic aerosol mass fraction, Atmos. Chem. Phys., 7, 3811-3821, doi:10.5194/acp-7-3811-2007, 2007a.

Pathak, R. K., Stanier, C. O., Donahue, N. M., and Pandis, S. N.: Ozonolysis of alpha-pinene at atmospherically relevant concentrations: Temperature dependence of aerosol mass fractions (yields), J. Geophys. Res.-Atmos., 112, D03201, doi:10.1029/2006jd007436, 2007b.

Paulot, F., Crounse, J. D., Kjaergaard, H. G., Kurten, A., St Clair, J. M., Seinfeld, J. H., and Wennberg, P. O.: Unexpected Epoxide Formation in the Gas-Phase Photooxidation of Isoprene, Science, $325,730-733,2009$.

Perraud, V., Bruns, E. A., Ezell, M. J., Johnson, S. N., Yu, Y., Alexander, M. L., Zelenyuk, A., Imre, D., Chang, W. L., Dabdub, D., Pankow, J. F., and Finlayson-Pitts, B. J.: Nonequilibrium atmospheric secondary organic aerosol formation and growth, $\mathrm{P}$. Natl. Acad. Sci. USA, 109, 2836-2841, 2012.

Presto, A. A. and Donahue, N. M.: Investigation of alpha-pinene plus ozone secondary organic aerosol formation at low total aerosol mass, Environ. Sci. Technol., 40, 3536-3543, 2006.

Presto, A. A., Hartz, K. E. H., and Donahue, N. M.: Secondary organic aerosol production from terpene ozonolysis. 2. Effect of $\mathrm{NO}_{\mathrm{x}}$ concentration, Environ. Sci. Technol., 39, 7046-7054, 2005.

Prisle, N. L., Engelhart, G. J., Bilde, M., and Donahue, N. M.: Humidity influence on gas-particle phase partitioning of alphapinene + O-3 secondary organic aerosol, Geophys. Res. Lett., 37, L01802, doi:10.1029/2009g1041402, 2010.

Pye, H. O. T., Chan, A. W. H., Barkley, M. P., and Seinfeld, J. H.: Global modeling of organic aerosol: the importance of reactive nitrogen $\left(\mathrm{NO}_{\mathrm{x}}\right.$ and $\left.\mathrm{NO}_{3}\right)$, Atmos. Chem. Phys., 10, 1126111276, doi:10.5194/acp-10-11261-2010, 2010.

Qi, L., Nakao, S., Tang, P., and Cocker III, D. R.: Temperature effect on physical and chemical properties of secondary organic aerosol from m-xylene photooxidation, Atmos. Chem. Phys., 10, 38473854, doi:10.5194/acp-10-3847-2010, 2010.

Rollins, A. W., Kiendler-Scharr, A., Fry, J. L., Brauers, T., Brown, S. S., Dorn, H.-P., Dubé, W. P., Fuchs, H., Mensah, A., Mentel, T. F., Rohrer, F., Tillmann, R., Wegener, R., Wooldridge, P. J., and Cohen, R. C.: Isoprene oxidation by nitrate radical: alkyl nitrate and secondary organic aerosol yields, Atmos. Chem. Phys., 9, 6685-6703, doi:10.5194/acp-9-6685-2009, 2009.

Rudich, Y., Donahue, N. M., and Mentel, T. F.: Aging of organic aerosol: Bridging the gap between laboratory and field studies. Annual Review of Physical Chemistry. Palo Alto, Annual Reviews, 58, 321-352, 2007.

Saathoff, H., Naumann, K.-H., Möhler, O., Jonsson, Å. M., Hallquist, M., Kiendler-Scharr, A., Mentel, Th. F., Tillmann, R., and Schurath, U.: Temperature dependence of yields of secondary organic aerosols from the ozonolysis of $\alpha$-pinene and limonene, Atmos. Chem. Phys., 9, 1551-1577, doi:10.5194/acp-9-15512009, 2009.

Sarwar, G. and Corsi, R.: The effects of ozone/limonene reactions on indoor secondary organic aerosols, Atmos. Environ., 41, 959973, 2007.
Schell, B., Ackermann, I. J., Hass, H., Binkowski, F. S., and Ebel, A.: Modeling the formation of secondary organic aerosol within a comprehensive air quality model system, J. Geophys. Res.Atmos., 106, 28275-28293, 2001.

Schmidt, M. and Lipson, H.: Distilling Free-Form Natural Laws from Experimental Data, Science, 324, 81-85, 2009.

Sciare, J., d'Argouges, O., Zhang, Q. J., Sarda-Estève, R., Gaimoz, C., Gros, V., Beekmann, M., and Sanchez, O.: Comparison between simulated and observed chemical composition of fine aerosols in Paris (France) during springtime: contribution of regional versus continental emissions, Atmos. Chem. Phys., 10, 11987-12004, doi:10.5194/acp-10-11987-2010, 2010.

Seinfeld, J. H., Erdakos, G. B., Asher, W. E., and Pankow, J. F.: Modeling the formation of secondary organic aerosol (SOA). 2. The predicted effects of relative humidity on aerosol formation in the alpha-pinene-, beta-pinene-, sabinene-, Delta(3)-Carene, and cyclohexene-ozone systems, Environ. Sci. Technol., 35, 1806-1817, 2001.

Seinfeld, J. H. and Pankow, J. F.: Organic atmospheric particulate material, Annual Rev. Phys. Chem., 54, 121-140, 2003.

Stanier, C. O., Donahue, N. M., and Pandis, S. N.: Parameterization of secondary organic aerosol mass fractions from smog chamber data, Atmos. Environ., 42, 2276-2299, 2008.

Stockwell, W. R., Kirchner, F., Kuhn, M., and Seefeld, S.: A new mechanism for regional atmospheric chemistry modeling, J. Geophys. Res.-Atmos., 102, 25847-25879, 1997.

Stone, D., Whalley, L. K., and Heard, D. E.: Tropospheric $\mathrm{OH}$ and $\mathrm{HO} 2$ radicals: field measurements and model comparisons, Chem. Soc. Rev., 41, 6348-6404, 2012.

Symeonidis, P., Gkantou, A., Melas, D., Yay, O. D., Pouspourika, E., Balis, D., and Poupkou, A.: Development of a computational system for estimating biogenic NMVOCs emissions based on GIS technology, Atmos. Environ., 42, 1777-1789, 2008.

Takekawa, H., Minoura, H., and Yamazaki, S.: Temperature dependence of secondary organic aerosol formation by photo-oxidation of hydrocarbons, Atmos. Environ., 37, 3413-3424, 2003.

Tillmann, R., Hallquist, M., Jonsson, Å. M., Kiendler-Scharr, A., Saathoff, H., Iinuma, Y., and Mentel, Th. F.: Influence of relative humidity and temperature on the production of pinonaldehyde and $\mathrm{OH}$ radicals from the ozonolysis of $\alpha$-pinene, Atmos. Chem. Phys., 10, 7057-7072, doi:10.5194/acp-10-7057-2010, 2010.

Tsimpidi, A. P., Karydis, V. A., Zavala, M., Lei, W., Molina, L., Ulbrich, I. M., Jimenez, J. L., and Pandis, S. N.: Evaluation of the volatility basis-set approach for the simulation of organic aerosol formation in the Mexico City metropolitan area, Atmos. Chem. Phys., 10, 525-546, doi:10.5194/acp-10-525-2010, 2010.

Ulbrich, I. M., Canagaratna, M. R., Zhang, Q., Worsnop, D. R., and Jimenez, J. L.: Interpretation of organic components from Positive Matrix Factorization of aerosol mass spectrometric data, Atmos. Chem. Phys., 9, 2891-2918, doi:10.5194/acp-9-2891-2009, 2009.

Vivanco, M. G., Santiago, M., Martinez-Tarifa, A., Borras, E., Rodenas, M., Garcia-Diego, C., and Sanchez, M.: SOA formation in a photoreactor from a mixture of organic gases and HONO for different experimental conditions, Atmos. Environ., 45, 708**715, 2011.

Warren, B., Austin, R. L., and Cocker, D. R.: Temperature dependence of secondary organic aerosol, Atmos. Environ., 43, 35483555, 2009. 
Yu, F.: A secondary organic aerosol formation model considering successive oxidation aging and kinetic condensation of organic compounds: global scale implications, Atmos. Chem. Phys., 11, 1083-1099, doi:10.5194/acp-11-1083-2011, 2011.

Yu, J. Z., Cocker, D. R., Griffin, R. J., Flagan, R. C., and Seinfeld, J. H.: Gas-phase ozone oxidation of monoterpenes: Gaseous and particulate products, J. Atmos. Chem., 34, 207-258, 1999.

Zhang, Q., Jimenez, J. L., Canagaratna, M. R., Allan, J. D., Coe, H., Ulbrich, I., Alfarra, M. R., Takami, A., Middlebrook, A. M., Sun, Y. L., Dzepina, K., Dunlea, E., Docherty, K., DeCarlo, P. F., Salcedo, D., Onasch, T., Jayne, J. T., Miyoshi, T., Shimono, A., Hatakeyama, S., Takegawa, N., Kondo, Y., Schneider, J., Drewnick, F., Borrmann, S., Weimer, S., Demerjian, K., Williams, P., Bower, K., Bahreini, R., Cottrell, L., Griffin, R. J., Rautiainen, J., Sun, J. Y., Zhang, Y. M., and Worsnop, D. R.: Ubiquity and dominance of oxygenated species in organic aerosols in anthropogenically-influenced Northern Hemisphere midlatitudes, Geophys. Res. Lett., 34, L13801, doi:10.1029/2007GL029979, 2007.
Zhang, X. and Seinfeld, J. H.: A Functional Group Oxidation Model (FGOM) for SOA formation and aging, Atmos. Chem. Phys. Discuss., 12, 32565-32611, doi:10.5194/acpd-12-32565-2012, 2012.

Zhou, Y., Zhang, H. F., Parikh, H. M., Chen, E. H., Rattanavaraha, W., Rosen, E. P., Wang, W. X., and Kamens, R. M.: Secondary organic aerosol formation from xylenes and mixtures of toluene and xylenes in an atmospheric urban hydrocarbon mixture: Water and particle seed effects (II), Atmos. Environ., 45, 3882-3890, 2011. 